The meteorologica] record for the week ending March 3, in Boston, was as follows, according to observations furnished hy Sergeant J. W. Smith, of the United States Signal Corps:-

\begin{tabular}{|c|c|c|c|c|c|c|c|c|c|c|c|c|c|c|c|c|c|c|c|}
\hline \multirow{2}{*}{$\begin{array}{c}\text { Week ending } \\
\text { Saturday, } \\
\text { Mar. 3, } 1888 .\end{array}$} & \multirow{2}{*}{$\begin{array}{c}\text { Barom- } \\
\text { eter. }\end{array}$} & \multicolumn{3}{|c|}{ Thermometer. } & \multicolumn{4}{|c|}{$\begin{array}{c}\text { Relative } \\
\text { Humidity. }\end{array}$} & \multicolumn{3}{|c|}{$\begin{array}{l}\text { Direction of } \\
\text { Wind. }\end{array}$} & \multicolumn{3}{|c|}{$\begin{array}{l}\text { Velocity of } \\
\text { Wind. }\end{array}$} & \multicolumn{3}{|c|}{$\begin{array}{c}\text { State of } \\
\text { Weather. }\end{array}$} & \multicolumn{2}{|c|}{ Rainfall. } \\
\hline & & 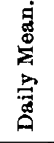 & 莺 & 劳 & 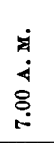 & में & $\begin{array}{l}\text { मे } \\
\dot{8} \\
\Phi \\
\Phi\end{array}$ & 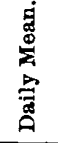 & $\begin{array}{l}\dot{1} \\
\dot{j} \\
\stackrel{8}{0}\end{array}$ & $\dot{\dot{x}}$ & में & $\begin{array}{l}8 \\
\dot{1} \\
0 \\
0 \\
0\end{array}$ & में & : & 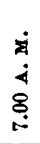 & 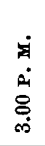 & $\begin{array}{l}0 \\
\dot{2} \\
8 \\
0 \\
0 \\
0\end{array}$ & 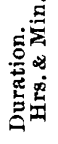 & 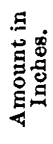 \\
\hline 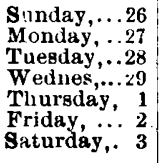 & $\begin{array}{l}29.66 \\
29 . \times 2 \\
30.17 \\
3030 \\
30.33 \\
30.21 \\
29.90\end{array}$ & $\begin{array}{l}41.0 \\
27.0 \\
13.0 \\
20.0 \\
29.0 \\
28.0 \\
27.0\end{array}$ & $\begin{array}{l}52.0 \\
37.0 \\
22.0 \\
28.0 \\
37.0 \\
34.0 \\
36.0\end{array}$ & $\begin{array}{r}36.0 \\
21.0 \\
11.0 \\
8.0 \\
10.0 \\
16.0 \\
20.0\end{array}$ & $\begin{array}{l}91.0 \\
77.0 \\
63.0 \\
64.0 \\
64.0 \\
89.0 \\
66.0\end{array}$ & $\begin{array}{l}57.0 \\
43.0 \\
50.0 \\
56.0 \\
43.0 \\
65.0 \\
47.0\end{array}$ & $\begin{array}{l}64.0 \\
59.0 \\
62.0 \\
67.0 \\
70.0 \\
72.0 \\
69.0\end{array}$ & $\begin{array}{l}71.0 \\
60.0 \\
58.0 \\
62.0 \\
59.0 \\
76.0 \\
61.0\end{array}$ & $\begin{array}{l}\mathbf{w} . \\
\mathbf{w} . \\
\text { N.w. } \\
\text { N.w. } \\
\text { N. } \\
\mathbf{N}: \\
\mathbf{w} .\end{array}$ & $\begin{array}{l}\mathbf{w} . \\
\mathbf{w} \\
\mathbf{w} \\
\mathbf{w} \\
\mathbf{w} \\
\mathbf{w} \\
\mathbf{w}\end{array}$ & $\begin{array}{l}\text { W. } \\
\text { N.w. } \\
\text { N.w. } \\
\text { N.w. } \\
\text { N. } \\
\text { w. } \\
\text { N.W. }\end{array}$ & $\begin{array}{r}8 \\
12 \\
14 \\
6 \\
5 \\
14 \\
4\end{array}$ & $\begin{array}{r}8 \\
8 \\
24 \\
12 \\
10 \\
7 \\
24\end{array}$ & $\begin{array}{r}10 \\
18 \\
8 \\
6 \\
2 \\
2 \\
11 \\
24\end{array}$ & $\begin{array}{l}\text { o. } \\
\text { F. } \\
\text { C. } \\
\text { c. } \\
\text { C. } \\
\text { C. }\end{array}$ & $\begin{array}{l}\text { F. } \\
\text { o. } \\
\text { C. } \\
\text { c. } \\
o . \\
\text { o. } \\
\text { c. }\end{array}$ & $\begin{array}{l}\text { o. } \\
\text { O. } \\
\text { F. } \\
\text { C. } \\
\text { o. } \\
\text { k. } \\
\text { C. }\end{array}$ & $\begin{array}{l}1 \\
0 \\
0 \\
0 \\
2 \\
2 \\
0\end{array}$ & $\begin{array}{l}.10 \\
0 \\
0 \\
0 \\
\mathrm{~T} . \\
\mathrm{T} . \\
0\end{array}$ \\
\hline $\begin{array}{l}\text { Mean, the } \\
\text { Week. }\end{array}$ & 30.057 & 26.4 & 35.0 & 17.0 & & & & 63.7 & & & & & & & & & & 5 & .10 \\
\hline
\end{tabular}

1 O., cloudy ; C., clear ; F., fair ; G., fog ; H., hazy ; S., smoky ; R., rain; T., threatening ; N., Snow ; *T., trace of rainfall.

OFFICIAL LIST OF CHANGES IN THE S'TATIONS AND DUTIES OF OFFICERS SERVING IN THE MEDICAL DEPAR'IMEN'T, U. S. ARMY, FROM MARCH 3, 1888, TO MARCH 9, 1888.

Fisher, W. W., first lieutenant and assistant surgeon. Sick leave extended one month on surgeon's certificate of disability. S. O. 50, A. G. O., March 2, 1888 .

Shillock, PaUL, first lieutenant and assistant surgeon; recently appointed. Ordered for duty at Fort Assinniboine, Mont. S. O. 50, A. G. O., March 2, 1888.

OFFICIAL LIST OF CHANGES IN THE MEDICAL CORPS OF THE UNI'TED S'IA'TES NAVY DURING THE WEEK ENDING MARCH 10, 1888.

Stonk, E. P., assistant surgeon. Detached from the Coast Survey steamer "Bache," and to Hospital, New York, for treatment.

Kener, James F., assistant surgeon. Commissioned March 1,1888 .

Brush, Georar R., surgeon. Ordered to the "Omaha" when "Pensacola" arrives at Aspinwall.

Mrans, Victor C. B., passed assistant surgeon. To the "Omaha" when "Pensacola" arrives at Aspinwall.

\section{SOCIETY NOTICE}

Massachusettrs Memical Society. Suffolk Drstrict. The Section for Obstetrics and Gynæcology, will meet at 19 Boylston Place, on Wednesday, March $21 \mathrm{st}$, at 7.45 o'clock. Dr. J. W. Farlow will report a "Case of Suppression of Urine for Thirteen Days, from Compression of Both Ureters," with specimen. The discussion will be opened by Drs. A. T. Cabot, R. H. Fitz, W. W. Gannett, and E. S. Wood.

J. W. FARLOW, M.D., Chairman.

"The Pinckney.' GmoRge Haven, M.D., Secretary.

\section{RESIGNATION}

Dr. G. W. West has resigned his position as Surgeon to Outpatients at the Massachusetts General Hospital.

OBITUARY. DR. CHARLES B. WELLINGTON.

Dr. Charles B. Wellington died in Cambridge, Mass., (where he was born), February 17, 1888, aged twenty-eight years. He graduated at the Harvard Medical School in 1885 . Not long afterward, at the opening of the New Cambridge Hospital, he was chosen the House Physician. After holding this office a year he resigned it, and became associated with his father, Dr. W. W. Wellington, in the general practice of his profession in W. W. Welling

$\mathrm{He}$ was a young man of singular sweetness of character and unusual professional promise, as will be seen from the follow: ing well-merited tribute paid to his memory by the Trustees of the Cambridge Hospital, who at a recent meeting of their Board:

Voted, That the Trustees have learned with much sorrow of the death of Dr. Charles B. Wellington, the first House Physi- Pre
cian of the Hospital; and they wish to place on record the high 1888. esteem in which they held him. They bear witness to his fidelity in the new duties which were assigned to him in the organization and administration of the Hospital ; to the constancy of his service; to the carefulness and ability of his professional work; and to the uniform courtesy and thoughtfulness and heartiness which marked his personal and official life.

His name will be cherished by all who have been associated with him; who have valued his friendship, and will tenderly preserve the memory of his generous and helpful life.

The Trustees desire to extend to the family of Dr. Wellington their profound sympathy at the removal of one whose char acter and spirit rendered him peculiarly endeared, and whose life held so much promise of usefulness and honor in the profession which was his heritage and choice.

\section{BOOKS AND PAMPHLETS RECEIVED.}

The Cure of Hernia. By Henry O. Marcy, A.M., M.D., of Boston, Mass. Reprint. 1887.

The Passage of Air and Fæces from the Urethra. By Harrison Cripps, F.R.C.S., Assistant Surgeon to St. Bartholomew's Hospital. London: J.\& A. Churchill. 1888.

The Cartwright Lectures of the Alumni Association of the College of Physicians and Surgeons of New York, for 1888, will be delivered at the College by Prof. Wm. H. Weleh, of Johns Hopkins University, on Thursday evenings, March 29 th, April 5th and 12 th, at 8.30 P.M. The subject will be the "General Pathology of Fever."

A Manual of Physiology; A Text-Book for Students of Medicine. By Gerald F. Yeo M.D., Dublin, F.R.C.S., Professor of Physiology in King's College, etc. Third American from second English Edition. With 321 illustrations and a glossary. Philadelphia: P. Blakiston, Son \& Co. 1888.

The Year-Book of Treatment for 1887; A Critical Review for Practitioners of Medicine and Surgery. Philadelphia: Lea Brothers \& Co. 1888.

On the Use of the Vaginal Tampon in the Treatment of Certain Effects following Pelvic Intlammations. By Thomas Addis Emmet, M. D. Surgeon to the Woman's Hospital in the State of New York, N. Y. Reprint. 1888.

Diseases of the Skin; A Manual for Practitioners and Students. By W. Allen Jamieson, M.D., F.R.C.P., Extra Physieian for Diseases of the Skin, Edinburgh Royal lnfirmary. With woodcut and eight colored illustrations Edinburgh: Young J. Bentland; Philadelphia: J.B. Lippincott \& Co. 1888.

Viseases of the Heart and Circulation in Infancy and Adolescence. By John M. Keating, M.D., Obstetrician to the Philadelphia Hospital, etc., and William A. Edwards, M. D., Instructor in Clinical Medicine, and Physician to the Medical Dispensary in the University of Pennsylvania. Illustrated with photographs and wood engravings. Philadelphia: P. Blakis ton, Son \& Co. 1888.

The Wills Eye Hospital, Philadelphia. Founded April 2, 1832. Report for the Year ending December 31, 1887.

1887. Tenth Annual Report of the Presbyterian Eye, Ear and Throat Charity Hospital, No. 1007 East Baltimore Street Baltimore.

A Very Valuable Lesson for Those who Use Anæsthetics. By Julian J. Chisolm, M.D. Professor of Eye and Ear Diseases in the University of Maryland, and Surgeon-in-Charge of the Presbyterian Eyo and Ear Charity Hospital of Baltimore City. 1888. 